\title{
İntihar Kavramının Çocuklar ve Ergenler Açısından Ele Alınması
}

\section{Conceptual Issues Concerning Suicide in Children and Adolescents}

\section{Seda BAYRAKTAR*}

Öz: Çocuk ve ergenlerde intihar girişiminin ve intiharın giderek artması önemli bir sorun haline gelmiştir. Genç ve dinamik bir nüfusa sahip olan ülkemizin sosyal, kültürel ve ekonomik yönden sürekli değişim içinde olması nedeniyle, çocuk ve ergenlerin ruhsal yaşamlarında ortaya çıkan "gel-gitler" önem taşımaktadır. Bu derleme kapsamında intihar girişimleri ve intiharla ilgili tanımlama ve kuramlara yer verilerek, çocuklar ve ergenler açısından intihar girişimi ve intihar ile ilgili risk etkenleri ve tetikleyici etkenler ele alınmıştır. Ülkemizdeki ve diğer ülkelerdeki çalışmalar; cinsiyet, yaş, ırk, medeni durum, sosyal etkenler, intihara ilişkin seçilen yöntemler, önceki intihar girişimleri, inanç, cinsel tercihler, mevsimler, göç, medya, fiziksel ve ruhsal etkenler açısından değerlendirilmiştir. İntihardan ölenlerin sayısı, trafik kazalarından ölenlerin sayısına yakın olup, alınacak önlemlerle trafik kazalarında olduğu gibi intihar girişimlerinin ve intiharların azalabileceği görülmektedir. Önleyici tedbirler arasında bireysel, ailesel, çevresel, toplumsal ve kamusal uygulamaların yerinin önemli olduğu bununla birlikte sağlam bir aile yapısı ve eğitimin; çocuk ve ergen mutluluğu için kaçınılmaz etkenler olduğu gözlenmiştir.

Anahtar sözcükler: Çocuk, Ergen, İntihar, İntihar Girişimi

Abstract: The increasing rate of attempted suicide and the suicide of children and adolescents is an important problem. The speed and quantity of social, cultural and economic changes in our country has effects upon a young and dynamic population. In consequence of these changes psychological/psychiatric problems may occur in the population and the aim of this review was to consider the definitions, theories, risk and precipitating factors associated with suicide attempts and with suicide in children and adolescents. Gender, age, race, marital status, family and social factors, the method chosen for the suicide, previous suicide attempts, beliefs, sexual orientation, season of the year, the role of the media and of migration were evaluated, in terms of the physical and psychological factors from the relevant literature. The number of deaths from suicide is close to the number of deaths from traffic accidents. Taking precautions may decrease the number of suicides and suicide attempts, as is the case for traffic accidents. The individual, family, environmental, social and public applications are important for effective preventive precautions however, a healthy family and educational structure are the most important factors for the happiness of the child and adolescent.

Keywords: Child, Adolescent, Suicide, Suicide Attempt

Doğmak, yaşamak ve ölmek canlılar için doğal bir olaydır. Sağlıklı yaşamak için çaba göstermek varken ölümü seçmek, insan için anlaşılması ve kabulü zor bir davranıştır. Bu derlemede genç ve dinamik bir nüfusa sahip olan Türkiye'nin toplumsal, kültürel, sosyal ve ekonomik yönden ciddi değişim geçirmesi nedeniyle bu olaylardan en çok etkilenen grubun başında çocuk ve ergenlerin olduğu gerçeğinden yola çıkılmıştır. 2014-2015 Eğitim ve öğretim

\footnotetext{
*Yrd. Doç. Dr., Akdeniz Üniversitesi, Edebiyat Fakültesi, Psikoloji Bölümü, Antalya. sedabayraktar@akdeniz.edu.tr
} 
döneminde 16.400 .000 öğrencinin ders baş1 yaptığı düşünülürse konunun ciddiyeti daha iyi anlaşılacaktır (www.egitimajansi.com/haber/okullar-aciliyor-yeni-egitim-ogretim-yilinda-nelerolacak-haberi-32448h-html). Çalışmanın amacı: Çocuk ve ergenlerde intihar düşüncesi, intihar girişimi ve intihar davranışı yönünden bireylerin, ailelerin, toplumun ve kurumların dikkatini çekmek ve konu hakkında farkındalık yaratabilmektir.

\section{Çocuk ve Ergenlerde Ölüm Algısı}

0-2 yaşlar arasındaki çocukta ölüm kavramı gelişmemiştir. Ölüm onlar için ayrılık anlamı taşımaktadır. 3-5 yaşlar arasındaki çocukta ölüm kavramı geri dönülebilir bir olay olarak algılanır ve yaşamın değişik bir şeklidir. Çocuk daha ziyade büyüsel bir düşünce içindedir. 6-11 yaşlar arasındaki çocuklar bilişsel olarak ölümün farkına varabilir. Ölümün bir sona erme ve fiziksel olarak bir yok oluş olduğunu algılar. 12-18 yaşlar arasında ise, ölümün evrensel ve kaçınılmaz olduğu gerçeği kavranmaya başlanır. Bunun kendisinin de başına gelebileceğini anlar (Erden 2002; Bildik 2013; Kıvılcım \& Doğan 2014). Çocuğun gözünde ölüm; ceza, hastalık, doğaüstü olay, uyku ve yolculuk gibi anlamlara gelir (Lorcu \& Bolat 2009; Y1lmaz 2013).

İntihar, Arapçada kurban anlamına gelen "narh” ve Avrupa dillerinde de kendini öldürmek anlamina gelen "sui homicide" kelimelerinden gelmektedir (Sarandöl 2003). Türkçe sözlük intiharı: "Bir kimsenin toplumsal ve ruhsal nedenlerin etkisi ile kendi hayatına son vermesi" şeklinde tanımlamaktadır (Akalın et al. 2011, 1199).

İntihar önemli bir halk sağlı̆g sorunudur (Arslan 2008). Dünya Sağlık Örgüt’ü verilerine göre intihar, ilk on ölüm nedeni arasında yer almaktadır. Bu durum ülkeden ülkeye ve toplumdan topluma değişmektedir (Yüksel 2001). İntihardan ölümler, Amerikan gençliği arasında 1024 yaş grubundaki ölüm nedenleri sıralamasında üçüncü sırada yer almaktadır (Kaplan \& Sadock 2004, 559). Shaffer ve Hicks'in (1993) bildirdiğine göre, ABD'de 15-19 yaşları arasındaki beyaz erkeklerde ölüm nedenleri arasında intihar ikinci sırada, Afrika kökenli Amerikal1larda ise, üçüncü sırada yer almaktadır (Miller \& Glinski 2000). Güney Kore'de yapılan bir çalışmada da ergenlerde intihar, ölüm nedenleri arasında ikinci sırada yer almaktadır (Park et al. 2006). İntihar, pek çok gelişmiş ülkede ergenlerin ölüm nedenleri arasında ilk sıralarda yer almaktadır (Ramey et al. 2010).

Dünya Sağlık Örgütü'nün 2003 yılında dünya genelinde 90 ülkede yaptığı bir araştırmaya göre, 15-19 yaş grubundaki gençler arasında intihar girişiminde bulunup ölenlerin oranı ortalama olarak 100.000'de 7,4 olup, bunların 10,5'ini erkekler ve 4,1'ini kızlar oluşturmaktadır. Genç intihar oranları bakımından Kazakistan, Belarus ve Rusya dünyada ilk üç sırayı paylaşmaktadir (Atasoy 2013).

21 Avrupa ülkesinde, 1980-1984 yılları arasında yapılan bir çalışmada, 5-14 yaş grubunda intihardan ölen erkeklerin oranı 100.000 'de 0,9 iken, kızlarda bu oran 0,3 dür. 15-24 yaşları arasında bu oran, erkeklerde 100.000'de 15,5, kızlarda ise 4,7 olarak verilmektedir (Moens et al. 1988).

TÜİK verilerine göre: 2012 y1lında ülkemizde 3225 kişi intihardan ölmüş olup kabaca intihar hızı 100.000'de 4,29'dur. Bu oran, 15-19 yaş arası erkeklerde 6,01, kadınlarda 5,58'dir. 20-24 yaş arası erkeklerde 7,84, kadınlarda 4,08'dir (www.tuik.gov.tr/PreHaberBultenleri.do?id= 15853). 2013 yılında ülkemizde 3189 kişi intihardan ölmüş olup, kabaca intihar hızı 100.000'de 4,19'dur. Bu oran, 15 yaş altı erkeklerde 0,40, kızlarda 0,50'dir. 15-19 yaş aras1 erkeklerde 6,57, kadınlarda 5,52'dir. 20-24 yaş arası erkeklerde 8,4, kadınlarda ise 3,94'dür (www.tuik.gov.tr/ PreHaberBultenleri.do?id=19049). 2012 yılında: Trafik kazalarından 3750 kişi ve 2013 yılında da 3685 kişi ölmüştür (http://www.tuik.gov.tr/PreHaberBultenleri.do?id=18510). İntihardan ve 
trafik kazalarından ölenlerin sayıları arasında çok az fark görülmektedir. Bu değerler, intihar olayının çok ciddi bir toplumsal olay olduğunu ortaya koymaktadır.

E. Durkheim’e $(2013,25)$ göre: “Kurbanın kendisi tarafindan, ölümle sonuçlanacağı bilinerek yapılmış olumlu ya da olumsuz bir edimin doğrudan ya da dolayl sonucu olan her ölüme intihar" denir. Bu şekilde tanımlanan ancak ölüm sonucu doğurmayan edim ise "intihar girişimi" olarak tanımlanır.

Bir kişinin ölme isteğini yansıtan ifadeler kullanması ya da bunu ifade etmese bile tutum ve davranışlarından, böyle bir niyete sahip olduğu kanaatine varılması "intihar düşüncesi” olarak tanımlanmaktadır (Atay \& Kerimoğlu 2003; Deveci et al. 2005; Gökçen \& Köylü 2011). İntiharla ilgili düşünce süreçleri; ölümle ilgili düşünceleri, intihar girişimi ile ilgili planları, kullanılacak yöntemin belirlenmesini ve intihar düşüncelerinin kabul edilebilirliğini içermektedir. İntiharla ilgili davranışlar ise, intihar girişimini ve intiharı içermektedir (Siyez 2006).

Sağlık Bakanlığı verilerine göre, ülkemizde 2010, 2011 ve 2012 yıllarında toplam 8835 kişi intihar nedeniyle ölmüş ve bu süre içinde 141.691 kişi de intihar girişiminde bulunmuştur. İntihar girişimleri, intiharların ortalama 16 katıdır (www.muhabir.net/saglik/artan-intiharlarstratejik-plana-dahil-edildi-h1343.html).

Ankara'da, 1998-2001 yılları arasında yapılan çok merkezli bir çalışmada: İntihar girişimi oranı 100.000'de 57,9 - 112,1 olarak bulunmuştur (Özgüven \& Sayıl 2003). Ergenlerde intihar girişimlerinin yaşam boyu yaygınlığının \%3,5 ile \%11 arasında olduğu bildirilmektedir. 1989 yılında Ankara'da yapılan bir çalışmada, intihar girişim sıklığı 100.000' de 107, 1995 yılında ise 100.000’de 113 olarak bulunmuştur (Atay \& Kerimoğlu 2003).

Değişik toplumlarda intihar sıklığı, 100.000 'de 10-40 arasında değişmekte olup, intihar girişimi oranı bunun 15 katı kadardır (Yüksel 2001). Ancak literatür verileri çok değişiktir. Ülkemizde yapılan bir çalışmada: İntihar düşüncesinin yaşam boyu yaygınlığ $\%$ \%,6, intihar girişiminin yaşam boyu yaygınlığı ise \%2,3'dür (Deveci et al. 2005). Dış kaynaklı bir çalışmada, erişkinler arasında yaşam boyu intihar girişim oranı \%1,1- 4,3 arasında değişmektedir (Moscicki 1997).

Kuramcılar, intiharı: Bir hiçliğe gidiş ya da bir yok oluş olarak tanımlarlar. İntihar konusunda görüş bildiren kuramcıların birleştikleri ortak nokta, intiharın her durumda kültürden bağımsız olarak açıklanamaz oluşudur (İnal 2011).

E. Durkheim, üç çeşit intihar tanımlamıştır. Bunlar:

1- Bencil intihar: Bireyin toplumsal çevresi ile bütünleşmemesi sonucu olan intihar olayıdır. Bireyi kendi başının çaresine bakmak durumunda bırakan etkenler ne kadar çoğalırsa intihar olayı da o oranda artar.

2- Elcil intihar: Bireyin aşırı toplumsal bütünleşmişliğinin baskısı altında kalması intihar olayını kolaylaştırmaktadır. Bunlar: Adetler, gelenekler, töre, dinsel, siyasal kurallar ve alışkanlıklardaki katı kurallar.

3- Kuralsızlık intiharı: Birey davranışlarında uyulacak standart ölçülerin bulunmamasindan ileri gelmektedir (Durkheim 2013, 7-8).

İlkel toplumlarda intihar olayı özel nitelik taşımaktadır. Bunlar:

1- Yaşl1lığın eşiğine ulaşan ya da ciddi hastalığa yakalanan erkeklerin intiharı.

2- Kocalarının ölümü nedeniyle kadınların intiharı.

3- Başkalarının ölümü üzerine onların maiyetlerinin ya da hizmetçilerinin intiharı.

Bu durumlarda insanın kendini öldürmesi bunu bir hak olarak görmesinden değil, kendisi için 
bir ödev olmasından dolayıdır. Kişi bu yükümlülüğü yerine getirmeyecek olursa yaptırım gerekmektedir. Bu yaptırım: Şerefini yitirme ve dini yönden cezaya çarptırılma şeklinde olmaktadır. Böyle bir girişim için birey kişiliğine verilen değerin çok az olması gerekir. Çünkü bu kişilik oluşmaya başlar başlamaz ona tanınan ilk hak yaşama hakkıdır (Durkheim 2013, 248-249).

Sayıl (2002)'a göre intihar, stres yaratan yaşam koşullarına tepki veren normal kişilerden, ağır ruhsal bozukluğu olan kişilere kadar geniş bir popülasyonda görülebilmektedir. İntihar girişiminde bulunan kişi gerçekten ölmek arzusunda olabileceği gibi, bu davranışlarında acısını, çaresizliğini ve umutsuzluğunu dile getirmek amacını da gütmüş olabilir (akt. Deveci et al. 2005).

İntihar düşüncesi, intihar girişimi ve intiharın kolayca anlaşılabilmesi için, çocuk ve ergenin gelişiminden kısaca bahsetmekte yarar vardır. Çoğu kez neden-sonuç ilişkileri buralarda yatmaktadır.

Gelişim, biyolojik ve çevresel etkiler sonucu zaman içinde bireyin davranışlarında, düşüncelerinde ve yapısında ortaya çıkan değişmeler olarak tanımlanır. Doğumdan hemen sonraki dakikalar, hem anne hem de bebeğin yeni duruma uyumları ve aralarındaki ilişki için önemlidir. Gebeliğin istenerek gerçekleşmesi, anne ile bebek ilişkisinde önemli yeri olan bir kuraldır. Annelik duygusu içgüdüsel olup, iletişim ve etkileşim biçimi karşılıklı ilişki ile belirlenir. Bebek ile anne arasında oluşan özel bağlanma, sağlıklı ruhsal gelişimdeki en önemli belirleyicidir (Can 2011, 3; Şener \& İşeri 2011, 23).

Anne sevgisinin bebeğe dengeli, sürekli ve tutarlı şekilde verilebilmesi, bebeğin beslenmesi için gerekli olan besinler kadar önemlidir. Çocukta anne yoksunluğu ne kadar erken aylarda başlarsa ortaya çıkan/çıkacak bozukluklar da o kadar ağır olur. Babaların çocuklar üzerindeki etkileri doğrudan ya da dolaylı yollardan olmaktadır (Ekşi 2011, 38,41).

Okul Öncesi Dönem (0-6): Kişiliğin şekillenmesinde esas olan sosyal ve duygusal gelişim bu dönemde olmaktadır. Çocuğun anne-babasıyla, kardeşleriyle ve akranlarıyla etkileşimi yaşam boyu sürecek sosyalleşmenin temellerini oluşturur. Okul öncesi dönemde anne ve babanın etkili bir model olması, çocuğun gelecekteki kişilik yapısını, duygu ve düşüncelerini doğrudan etkiler (Say1l 1997, 133-134; Yavuzer 2001, 115).

Okul Dönemi (6-12): Bu dönemde çocuklar bilişsel yönden kendi başarı ve başarısızlıklarına ilişkin değerlendirme yapabilecek olgunluktadırlar. Kendilik gelişimi ile ilgili önemli gelişmeler arasında, çocukların kendilerini daha çok yetenek ve yeterlilik gibi içsel özelliklerle tanımlamaları, kendi görüş ve yeteneklerini başkaları ile karşılaştırmaları gelmektedir.

Anne-baba tutumları ile ilgili olarak çocuklar: Popüler çocuklar, saldırganlıkları veya çekingenlikleri nedeniyle reddedilen çocuklar, hem sevilen hem de sevilmeyen çocuklar ve arkadaşları tarafından pek istenmeyen unutulan çocuklar olarak ayrılabilir (Salk 1982, 184, 212; Sayıl 1997, 135-136; Gençtan 2012, 42-43).

Ergenlik Dönemi (12-18): Ergenlikten yetişkinliğe sağlıklı geçişin en önemli koşulu kimlik kazanmadır. Bu dönemde bir yandan cinsellik ve akranları ile olan ilişkilerden kaynaklanan bocalamalar, diğer yanda da aile bağlarının zayıflaması ile kendini gösteren duygusal çelişki sorunları vardır.

12-14 Yaşları arasında ilgi gelişen ve değişen bedene yöneliktir. Cinsel çatışma ve korkular yaşanabilir. 15-17 yaşları arasında, aileden bağımsız olma çabaları artar, uzaklaşma ve bağımsızlık isteği yanında ailenin sevgi ve desteğine gereksinim duyar. Aileden uzaklaştığı zaman; yalnızlık, güvensizlik ve güçsüzlük hisseder. Ergenlik döneminde görülen en ciddi psikolojik sorunlar bu dönemdedir. 
Ergen, 18 yaş ve üstü dönemde kendi kişiliğini bulmuş, bağımsızlaşma ve kendi kararlarını verebilme yetilerini kazanmıştır. Daha gerçekçidir, çatışmalardan kurtulur ve ayakları yere basar hale gelir (Ziyalar 1999,137-138; Ekşi 2011, 128-129,136-137; Gençtan 2012, 35).

Ergen ve aile arasındaki etkileşimlerde ailelerin en çok yakındıkları olumsuzluklar: Söz dinlememe, karşı gelme, uygunsuz arkadaşlar seçme, ailenin yaşam kurallarını bozma, dağınıklık, odasına kapanma, yüksek sesle müzik dinleme vb.leri. Bunlar, ergenin ailesinden ruhsal bağımsızlığını kazanma ve bireysel kimliğini edinme yolundaki olağan davranışlarıdır (Şenel \& İşeri 2011, 30).

\section{Etiyoloji}

1. Genetik Etkenler: Duygudurum bozukluklarında bu konu önem taşımaktadır. Anne ya da babasında depresif duygudurumu görülen çocuklarda iki kat, hem annesi hem de babasında depresif duygudurumu görülen çocuklarda (18 yaş altı) dört kat daha fazla duygudurum bozukluğu görülmektedir. $\mathrm{Bu}$ durum genetik olmanın ötesinde, yatkınlık ya da aile soy ağacındaki duygusal yüke bağlı olabilir (Kaplan \& Sadock 2004, 555).

Genetik etkenlerin rolünün psikiyatrik bozukluklar ve psikolojik uyaranlara bağımlı olmaksızın tek yumurta ikizlerinde \%30-50 arasında, çift yumurta ikizlerine göre daha fazla olduğunu göstermektedir. İntihar düşüncesi ve intihar girişimi ile ilgili olarak ikizler üzerinde yapılan bir çalışmada, tek yumurta ikizlerinde eş hastalanma oranı daha yüksek bulunmuştur (Statham et al. 1998; Özsoy \& Eşel 2003; Özalp 2009).

İntihar için genetik yatkınlığın psikiyatrik durumlardan bağımsız veya ona ek olduğu düşünülmektedir. İntihar girişiminde bulunan ergenlerin aile bireylerindeki intihar girişim oranı \%22, annelerinde ise \%50'dir (Roy et al. 1997).

2. Biyolojik Etkenler: İntihar konusunda, beyin biyokimyası, nörotransmitterler ve başka maddelere bağlı birç̧ok neden ileri sürülmüştür. En çok üstünde durulan kimyasal madde seratonindir. Seratoninin saldırganlık üzerinde baskılayıcı etkisi vardır. İntihar girişiminde bulunan depresyonlu kişilerin beyin omurilik sıvısında seratonin düzeyi düşük bulunmuştur (Yüksel 2001; Özsoy \& Eşel 2003).

3. Psikolojik Etkenler: Psikososyal açıdan intihara ilişkin çok sayıda yaklaşım vardır. Bunların önemli olan iki tanesinden kısaca bahsedilecektir. Diğerleri genellikle tamamlayıcı yaklaşımlardir.

a- E. Durkheim’in Toplumsal Yönelimli Kuramı: Durkheim'e göre intihar: Birey ile toplum arasındaki ilişki bozukluğundan ve çatışmalardan kaynaklanmaktadır. Toplumsal intihar oranını belirleyen değişken, intihar olayı ile birlikte görülen bazı toplumsal etkenlerdir. Bunlar: Aile koşulları, kent yaşamı, inanç, yaş, ekonomik düzey, ekonomik kriz, savaş vb.leridir (Durkheim 2013, 7).

b- S. Freud'un Psikanalitik Kuramı: Bu kurama göre intihar: Depresyonla ilgilidir ve depresyonun sonunda ortaya çıkan en ağır durumdur. Depresyonda, hayalde ya da gerçekte bir sevgi nesnesinin kaybı vardır ve buna bağlı olarak kişinin benliğinde bir yoksullaşma, boşluk ve terk edilmişlik duygularıyla birlikte, öz değerde belirgin azalma veya yok olma vardır. Bu görüşe göre depresyon, kaybedilen nesneye karşı duyulan düşmanca duyguların ve saldırgan dürtülerin kişinin kendine dönmesidir. Kişi kaybedilen nesne ile özdeşim kurar. Bu durum, kaybın oluşturduğu travmaya ve onun ruhsal sonuçlarına karşı bir savunmadır. Alt benlik, benlik ve üst benlik arasında bir çatışma vardır. Bunun sonucu olarak benlik saygısı düşer ve kişi kendini suçlamaya başlar. Benlik, üst benlik tarafından sıkıştırıldıkça hırpalanma ve yaşamdan uzaklaşma artar. Bunun sonucu 
olarak da intihar düşüncesi oluşur. Benlik, üst benliğin baskılarına dayanamaz hale gelince de kendisini yok etmeye (intihara) yönelebilir. Bu kurama göre intihar, depresyonla ilgilidir ve depresyonun sonunda ortaya çıkan en ağır durumdur (Cüceloğlu 2000, 456; Özsoy \& Eşel 2003; Akvardar et al. 2006, 60,78,167).

\section{Risk Etkenleri ve Tetikleyiciler}

1. Cinsiyet: İntihar girişimi oranı ergen kızlarda ergen erkeklerden en az üç kat daha fazladır. Ergen erkeklerde ise intihar oranı, kızlardan en az beş kat daha fazladır (Kaplan \& Sadock 2004, 559). Bir çalışmada, kızlarda intihar girişimleri daha ölümcül bulunmuştur (Sayar \& Acar 2000).

21 Avrupa ülkesinde 1980-1984 yılları arasında yapılan bir çalışmada, 5-14 yaş grubu erkeklerde intihar oranı ortalama 100.000 'de 0,9 iken, kızlarda bu oran 0,3'dür. 15-24 Yaş grubunda ise, erkeklerde intihar oranı ortalama 100.000 'de 15,5 iken, kılarda bu oran 4,7'dir (Moens et al., 1988). Başka ülkelerdeki çalışmalardan farklı olarak Çin'in kırsal kesiminde genç kadınlardaki intihar oranı, genç erkeklerden daha fazla bulunmuştur (Hawton 2000).

1997 yılında Avustralya'da 25 yaş altı 525 kişi intihar nedeniyle ölmüş olup bunların 425'i erkek ve 100'ü kadındır. Kadın/erkek oranı yaklaşık 1/4'tür. 1995-1996 yıllarında Avustralya'da, intihar ve intihar girişim oranları: 15-24 yaşları arasındaki erkeklerde intihar oranı 100.000 'de 26,1 ve intihar girişimi oranı 100.000 'de 174 'tür. Aynı yaş grubundaki kadınlarda ise, intihar oranı 100.000 'de 5,7 iken, intihar girişimi oranı 100.000'de 295'dir. İntiharda erkekler, intihar girişiminde ise kadınlar öndedir (Ruzicka \& Choi 1999). Dört ülkede yapılan 112.508 kişilik bir çalışmada, intihar girişimi kızlarda \%52,3, erkeklerde \%47,7 olarak bulunmuştur (Crepeau-Hobson \& Leech 2014). 2012 yılında ABD'de yapılan bir çalışmada, kızlarda \%49,9, erkeklerde \%48,6 oranında intihar girişimi gözlenmiştir (Pisani et al. 2013).

İntihar girişimi konusunda Türkiye'de yapılan bazı çalışmalarda alınan sonuçlar: \%75 kadın, \%25 erkek (Akın \& Berkem 2000), \%72,2 kadın, \%27,8 erkek (Erşan \& Kılıç 2013), \%56 kadın, \%44 erkek (Eskin 2000), \%73,3 kadın, \%26,7 erkek (Aysev 1992), \%86 kadın, \%14 erkek (Öztop et al. 2009), \%89,7 kadın, \%10,3 erkek (Aktepe et al. 2006), \%82,6 kadın, \%17,4 erkek (Gökçen \& Köylü 2011), \%76,2 kadın, \%23,8 erkek (Soylu et al. 2013), \%85 kadın, \%15 erkektir (Alsancak et al. 2010).

Yerli çalışmalardaki intihar girişimlerinde ortaya çıkan ortalama sonuç: \%77 kadın ve \%23 erkektir. Kadın/Erkek oran1 = 3,35/1'dir.

TÜIK 2013 verilerine göre tüm yaş gruplarında intihar edenlerin \%72,7’si erkek, \%27,3’ü kadındır (www.tuik.gov.tr/PreHaberBültenleri.do?id=16049).

Kızlarda intihar düşüncesi ve intihar girişimi daha fazla, erkeklerde ise intihar daha fazladır. Ancak bu cinsiyet farklılığı, her bölge ya da ülke için aynı değildir (Atay \& Kerimoğlu 2003). $\mathrm{Bu}$ oran bazı ülkelerde eşittir. Sadece Çin'de tamamlanmış intiharlar kadınlarda daha fazladır (Hawton 2000).

2. Yaş Dağılımı: TÜİK verilerine göre 2012 - 2013 yıllarında, erkek intiharları en çok 20-24, kadın intiharları ise 15-19 yaşları arasında görülmüştür (www.tuik.gov.tr./PreHaberBultenleri. do?ig=15853; www.tuik.gov.tr./PreHaberBultenleri.do?id=16049). Dünya Sağl1k Örgütü’nün desteği ile 1998-2002 yılları arasında ülkemizde yapılan çok merkezli bir çalışmada: İntihar girişim hızı \%93,59 artış göstermiş olup, intihar girişiminde bulunanların çoğunu 15-19 yaşları arasındaki gençler oluşturmaktadır( Özgüven \& Sayıl 2003).

Ülkemizde yapılan intihar girişimi konusundaki ergen çalışmalarından bazılarının sonuçları: 
15-24 yaş grubunun fazla olduğu çalışmalar (Ceyhun \& Ceyhun 2003; Ertemir \& Ertemir 2003; Arslan et al. 2008). 15-16 yaş grubunun fazla olduğu çalışma (Aktepe et al. 2006). 12-17 yaş grubunun fazla olduğu çalışma (Ünlü et al. 2014). Bu çalışmalardan çıkan ortak sonuç: İntihar girişimleri genellikle 12-24 yaşları arasında olmaktadır.

Sağlık Bakanlığı verilerine göre 2013 yılında psikiyatrik sorunlar nedeniyle, çocuk psikiyatri polikliniklerine muayene için götürülen çocukların sayıları oldukça fazladır. Bir yıl içinde,10-14 yaşları arasında 249.176 çocuk, 15-19 yaşları arasında da 556.999 çocuk, çocuk psikiyatri polikliniklerinde muayene olmuştur (Haberciniz.biz/uç-yilda-9-bin-kisi-intihar-etti 3155788h.html).

İntihar girişiminde bulunan kız çocuklarının çoğu ergendir. Bunun en önemli nedeni: Kız çocuklarının erkek çocuklardan önce olgunlaşması ve erkeklerle sevgiye dayalı ilişkilere girmesi olarak yorumlanmaktadır (Algın 2002).

ABD'de 15-19 yaş arası ergenlerde tamamlanmış intihar oranı 100.000'de 10'dur. İntihar girişimi ise en az 10 kat daha fazladır. Tamamlanmış intihar oranı 14 yaşın altındakilerde 100.000 'de 1'den azdır. İntihar girişimi ise, intihardan 50 kat daha fazladır (Kaplan \& Sadock 2004, 559).

Avrupa ülkelerinde intihar oranı en fazla 15-24 yaşları arasında görülmektedir (Moens et al. 1988). Avustralya'da 1995-1996 yıllarında yapılan bir çalışmada, en fazla intihar girişimi ve intiharın, 15-24 yaşları arasında olduğu görülmüştür (Ruzicka \& Choi 1999). Dört ülkede yapılan bir çalışmada, intiharın 10-19 yaşları arasındaki ergenlerin ölüm nedenleri arasında üçüncü sırada yer aldığı görülmektedir (Crepeau-Hobson \& Leech 2014).

3. Irk: ABD'de yapılan çalışmalarda, beyaz ve yerli Amerikalı gençlerde intihar girişim ve intihar oranları, siyah Amerikalılardan daha fazladır. Bu durum kırsal bölge ve şehir merkezlerinde değişebilir (Verona \& Javdani 2011). Aynı ülkede 2010-2012 yılları arasında 30 okul ve 7978 öğrenci arasında yapılan bir çalışmada: Siyah Amerikalılarda intihar girişimi \%8,4, yerli Amerikalılarda \%14,9, beyazlarda \%7,5 ve İspanyol asıllılarda \%16,1 olarak bulunmuştur (Pisani et al. 2013).

4. Medeni Durum: Genel olarak boşanmış, dul ve bekar insanlarda intihar riski daha yüksektir (T.C. Sağlık Bakanlığı Temel Sağlık Hizmetleri Genel Müdürlüğü, İntiharın Önlenmesi Hekimler Iç̧in Kaynak 2004, 12; Durkheim 2013, 194). Mutsuz bir evlilik yaşayan ve boşanmanın olmadığı toplumlarda evli kadınların intihar oranları bekarlardan daha fazladır. Çok erken evlilikler, kadın ve erkekler için intihar konusunda ağırlaştıııcı etki yapar. Evlilikte çocukların varlığı kadın yönünden avantaj sağlamaktadır. Çocukların umutlandırıcı etkisine kadınlar erkeklere göre daha duyarlıdır. Mutlu ve korumacı bir aile ortamı, çocuk ve genç intiharları konusunda engelleyici özellik taşımaktadır. Kadın ve erkek intiharlarında evliliğin kendine özgü bir koruyucu etkisi vardır (Durkheim 2013, 198, 211). Uyumlu bir evlilik yaşayanlarda intihar riski düşük, boşanmalarda ve bekarlarda yüksektir. İntihar yönünden evlilik, erkeklerde koruyucu bir etki yapsa da kadınlarda anlamlı bir farklılık yoktur (Sarandöl 2003).

Medeni durumlarına göre intihar girişim oranları: \%67,7 bekar, \%32,3 evli (Ertemir \& Ertemir, 2003), \%56 bekar, \%42 evli (Şevik et al. 2012). Avustralya'da 1991-1996 dönemine ait bir çalışmada, yalnız yaşayan 10-19 yaş arası erkeklerde intihar oranı 100.000'de 9, evli olanlarda 100.000'de 7'dir. 20-29 Yaş aralığında yalnız yaşayanlarda intihar oranı 100.000'de 38,5, evli olanlarda ise 100.000'de 14,8'dir (Ruzicka \& Choi 1999).

Medeni durum konusunda çocuk gelinlerin ayrı bir yeri vardır. Bunların büyük bir kısmı daha on'lu yaşlarda okula gitmesi gerekirken ev işleri ve kadınlık yapmakta, erken yaşlarda 
doğurmakta, koca ve çevre baskılarına maruz kalmaktadır. Bazen köle gibi çalıştırılmakta ve psikolojik bunalımlarla dolu bir yaşam sürmektedir. Bu bunalımlara dayanamayanlar intihar etmektedir (Kılıç 2012).

TÜİK 2012 verilerine göre: İntihar edenlerin \%50'si evli, \%36,7'si hiç evlenmemiş,\%5,9’u boşanmış. Erkeklerde evli olanlarda, kadınlarda ise hiç evlenmemiş olanlarda intihar oranı yüksektir (www.tuik.gov.tr./PreHaberBultenleri.do?id=15853). 2013 verilerine göre: İntihar edenlerin \%48,8'i evli, \%38,4'ü hiç evlenmemiş,\%5,6'sı boşanmış. Burada da erkeklerde evli olanlar, kadınlarda ise hiç evlenmemiş olanlarda intihar oranı yüksektir (www.tuik.gov.tr./ PreHaberBulteni.do?id=16049).

5. Aileye ve Çocuğa Bağlı Etkenler: Genellikle sorunlu aile ortamlarında büyüyen çocuklar, anne-babaların gergin, soğuk, saldırgan, kavgacı, destekten mahrum ve cezalandırıcı davranışları ile karşı karşıya kalabilmektedir. Çocuk gelişiminde mutlu bir aile ortamı önemlidir. Evin sürekli kavga, korku ve kaygı kaynağı olması, çocuk gelişimine vurulabilecek en büyük darbedir (Sayar \& Bağlan 2010, 234).

Aile içi olumlu ilişkiler, çocukların rahatlığının, bağlılığının ve mutluluğunun kaynağı olup sorumluluk ve yükümlülüğü de beraberinde getirir. Psikolojik sorunlar bireyin ilişkilerini etkilemektedir. İlişki kopukluğu ya da kaybı, izolasyon ve depresyon duygularının gelişimiyle sonuçlanmaktadır. Aile içi şiddet olumsuz davranışları beraberinde getirir (Kumbasar 1998, 817-818). Aile işlevi ergen intihar olaylarında etkilidir. Lester’a (1989) göre, aile içinde samimi olmayan, güvensiz ve sorun çözmeye yönelmeyen ilişkiler intihar davranışını zemin hazırlamaktadır (akt. Dilsiz 1993).

İntihar eden gençlerin aileleri incelendiğinde: Babanın kendine güvensiz ve depresyonda, annenin endişeli ve intihar düşüncesi taşıdığı saptanmıştır. Aile ilişkilerinde bozukluk ve alkolmadde kullanım alışkanlığı intihar tetikleyicilerindendir (Çitak 2011, 550).

Aile Sorunları: Parçalanmış aile, boşanmalar, anne-baba ayrılığ 1 , anne-babanın yeniden evlenmesi, sadece anne ya da babanın kaybı veya her ikisinin kaybı, üvey kardeşin varlığı, aile içi şiddet, aile içinde intihar ya da intihar girişimi yaşanması, alkol ve madde kullanımı, aile içi fiziksel, cinsel, duygusal istismar ve ihmallerin varlığı, aile içi iletişim kopukluğu ya da yetersizliği, ailede olumsuz ilişkiler, aile-çocuk ilişkisi tipleri, sosyal ve ekonomik krizler, annebabanın eğitim düzeyi, erken evlilikler, sosyal izolasyon, yalnızlık, anne-baba da bulunan ruhsal sorunlar ve hastal1klardır (Yoder et al. 1998; Eskin 2001; Ceyhun \& Ceyhun 2003; Öztop et al. 2009).

Aile ve sosyal desteği düşük olan bireylerde intihar girişimi yüksektir (Soylu et al. 2013). 15-24 yaşları arasında en çok intihar girişim nedeni ailesel sorunlardır (Erşan \& Kılıç 2013; Yalaki et al. 2011). Güney Koreli öğrenciler arasında yapılan bir çalışmada, aile ve arkadaşlarla kolay ya da zor ilişki kuruyor olmakla, intihar düşüncesi arasında ilişki olduğu bildirilmektedir. Çalışmada erkeklerin duygularını bastırmaya, kızların ise paylaşmaya özendirildikleri hatırlatılarak, kızlarda olduğu gibi, erkeklerde de intihar düşüncelerini etkileyen etkenler arasında "arkadaşları ile kolay ilişki kurma" değişkeninin önemi vurgulanmaktadır. Ailesi ve arkadaşları ile kolay iletişim kuran kız ve erkeklerin intihar düşüncelerinin, zor iletişim kuranlardan daha az olduğu vurgulanmaktadır (Park et al. 2006).

Ailenin ilk çocuklarında intihar girişimi diğerlerinden daha yüksektir (Aysev 1992; Çetin Çuhadaroğlu 2001). Fiziksel zorbalık, siber zorbalık, madde kullanımı, şiddet davranışı ve güvenli olmayan cinsel davranışın intihar davranışı ile ilişkili olduğu ifade edilmektedir (Litwiller \& Brausch 2013). Çocukluk çağındaki cinsel, fiziksel, duygusal istismar ve ihmaller, 
ergenin intihar düşüncesi ve intihar girişimi ile yakından ilişkilidir (Miller et al. 2013). Aileden birisinin intihar etmiş olması ve yakın arkadaşının intihar girişimine tanık olması, ergenin intihar riskini artırır. Medyadaki intihar haberlerin veriliş şekli ve süresi de ergen intiharları üzerinde etkili olmaktadır (Crepeau-Hobson \& Leech 2014).

Çalışmalara göre ergenlerin intihar girişimi ile ilgili başlıca tetikleyiciler ve nedenleri: Ailevi ve aile içi sorunlar, anne-babanın kullandığı otorite tipi, anne ve babası tarafindan sevilmeyen ve istenmeyen çocuk olma algısı, karşı cinsle ilgili sorunlar (reddedilme, terk edilme, bozuşma), sosyal çevre ve okul sorunları, cinsel, fiziksel ve duygusal istismar, iletişim sorunları (aile, çevre, arkadaş ve okul), yalnızlık, kardeşin olmaması, aile içinde intihar girişimi öyküsünün olması, arkadaşının intihar girişiminde bulunması ya da intihar etmesi, alkol ve madde kullanımı (Moscicki 1997; Yoder et al. 1998; Leskela et al. 2004; Ulusoy et al. 2005; Park et al. 2006; Arslan et al. 2008; Alsancak et al. 2010; Gökçen \& Köylü 2011; Yalaki et al. 2011; Erşan \& Kılıç 2013, Ünlü et al. 2014). Ergen intiharları ile ilgili bir çalışmada (normallere göre): Annesi intihar etmiş ergenlerde beş kat, babası intihar etmiş ergenlerde iki kat daha fazla intiharın görüldüğü bildirilmiştir (Agerbo et al. 2002). Bazı alt gruplarda intihar düşüncesi ve girişimlerinin yaygınlığı diğerlerine kıyasla daha yüksektir. Yapılan bir çalışmada, evden kaçıp sokakta yaşayan 297 ergenin \%53,9'unun kendini öldürmeyi düşündüğü, \%26,3'ünün de kendini öldürmek için intihar girişiminde bulunduklarını gözlemlemişlerdir (Yoder et al. 1998).

Namus suçları ve zorlanmış intiharlar kadınlara karşı uygulanan şiddetin aşırı biçimlerinden biridir. 18 yaşın altındaki kızlar da namus suçlarının mağdurları arasında yer almaktadır. Ceza Kanunu'nda: Bir kişiyi intihara zorlamak suçtur. Eylemlerin sonuçlarını kavrayabilme ehliyeti bulunmayan bir kimse üzerinde intihar etmesi yönünde baskı kurulması da cinayet olarak nitelendirilmektedir (Gündoğmuş et al., 2004; http://www.izmiriplanlıyorum.019/static/upload/file/ turkiye'de_cocuklarin_durumu_raporu_pdf 2011).

İntiharla ilgili çalışmalar gözden geçirildiğinde, genç olmak (15-24 yaş arası), umutsuzluk ve yalnızlık duygularını yoğun bir biçimde yaşamak ve yaşamı sürdürmek için az sayıda nedene sahip olmak ( yaşamdan beklentinin olmaması) önemli risk etkenleri arasında bulunmaktadır (Batıgün 2005). Umudunu tümüyle kaybeden insan yaşamaktan kaçar, kaybedilen umut yıkıc1lığa, şiddete, kine ve nefrete dönüşür. Umut, hayat denilen binanın temel taşıdır (Bayraktar 2012, 166).

Lise ve üniversite öğrencileri arasında yapılan bir çalışmada, intihar düşüncesi ile umutsuzluk arasındaki korelasyon yüksek bulunmuştur (Ceyhun \& Ceyhun, 2003). Bu yaş grubunda intihar girişimlerinin yüksek olmasının nedenleri arasında, ülkemizde yaşanan sosyal değişimlere bağlı olarak ortaya çıkan kuşak çatışmaları, geleneksel aile yapısını sürdürmek isteyen anne ve babalar tarafindan gençlere uygulanan baskı ve kısıtlamalar sayılabilir. Gençler arasında artan alkol- madde kullanımı: Gençlerin intiharı bir protesto yöntemi ya da bu yaşantılardan bir kaçış yolu olarak kullanması biçiminde açıklanabilir (Ziyalar 1999, 137-138; Ceyhun \& Ceyhun 2003).

Düzenli olarak yapılan fiziksel aktiviteler (spor etkinlikleri) erkek ergenlerde umutsuzluk ve intihar riskini azaltmaktadır. Düzenli yapılan spor, her iki cinsiyet için umutsuzluk ve intihar riski açısından koruyucu etki yapmaktadır (Taliaferro 2008). Başka bir çalışmada da spor etkinliklerinin ergenlerin intihar düşüncesi ve intihar girişim oranlarını düşürdüğü gösterilmiştir (Ramey 2010).

Yalnızlık, bireyin var olan sosyal ilişkileri ile olmasını istediği sosyal ilişkiler arasındaki farklılı̆̆ algılaması sonucu yaşanan ve hoş olmayan bir psikolojik durum olarak tanımlanabilir. 
Yalnızlık, bireyin sosyal ilişkilerinde önemli eksikliklerinin olduğunun bir göstergesidir (Batıgün 2008).Yalnızlık, bireyin kaçınmak için her şeyi yaptığı, acı veren, korkutucu bir yaşantıdır. Terk edilme, vazgeçilme ve tehlikeye maruz kalma duygularını içerir. Yalnızlığın acı veren niteliği, bireyi ondan uzak kalma ya da ona karşı durma çabalarına iter (Tükel 2006, 39).

Herkes yaşamında zaman zaman yalnızlık duyar. Önemli olan bireyin bu duygu ile nasıl baş ettiğidir. Kişilerin kullandığı bazı baş etme yöntemleri: Kitap okuma, müzik dinleme, televizyon izleme, ilişki arama, uyuma, ağlama, düşünme ve hayal kurma gibi yollardır. Ergenler arasındaki yalnızlık duygularının hem intihar düşüncesi hem de intihar girişimi ile ilgili olduğu gözlenmiştir. Çevresi ile ilişki kurarak yalnızlığı ile baş etmeye çalışan ergenlerin intiharla ilgili davranışlarının daha az olduğu görülmüştür (Eskin 2001).

İnsanların karşılaştıkları sorunlarla olumlu yönde baş edebilmeleri ve sonrasında da gelişim kaydetmeleri, önemli psikolojik kazanımlar arasındadır. Onun için başa çıkma ve travma sonrası gelişimden (büyümeden) kısaca bahsetmekte yarar vardır.

\section{Başa Etme (Başa Çıkma)}

Başa etme kavramı psikoloji alanında oldukça önemlidir. Klinik tanımlama, değerlendirme, eğitim programlarının ve psikoterapi yaklaşımlarının düzenlenmesinde temel bir kavramdır (Folkman \& Lazarus 1984, 117). İnsanlarda yaşanan strese, duygusal ve fiziksel gerginliğin de eşlik etmesi insanları rahatsız eder ve insanlar bu stresi azaltmak için motive olurlar. Bireylerin stresi azaltmada kullandıkları yollar da baş etme içinde yer alır. Baş etme süreci tekil bir olay değildir. Çünkü baş etme çevreyle devam eden işler yapmayı içerir. Bireyler stresle bilişsel ve çevresel değişkenleri kullanarak baş ederler (Sarafino 2006, 117). Baş etme kavramına dair pek çok tanım bulunmaktadır. Folkman ve Lazarus: "Bireyin kişisel kaynaklarını aşan belirli iç ve dış isteklerle baş etmek için kullanılan ve sürekli olarak değişen bilişsel-davranışsal çabalar" olarak tanımlamaktadırlar (Folkman \& Lazarus 1984, 141.)

Bir çalışmada: İntihar girişimlerinin nedenlerinin başında sorunlarla baş edemeyeceğini düşünerek ölümü kurtuluş olarak görme düşüncesi \%74,19 olarak bulunmuştur. Genç intihar girişimlerinde, gençlerin sorunlara karşı tahammülsüz oluşunun, baş etme becerilerinin ve alternatif çözümler bulma becerilerinin gelişmemiş olmasının önemli bir rolü vardır (Ertemir \& Ertemir 2003).

Ergenlerdeki intihar düşüncesinde, umutsuzluk, dürtüsel davranışlar, öfke, saldırganlık ve problem çözme becerilerindeki yetersizlikler ön plana çıkmaktadır (Batıgün 2005). Yaşamı sürdürme nedenleri güçlü olan bireyler, stres ve umutsuzluğa karşı daha iyi direnebilmekte ve daha az intihar düşüncesine sahip olmaktadır (Batıgün 2008).

İntihar girişimi olan kişilerin, olmayan kişilere göre işlevsel baş etme tutumlarını daha az, işlevsel olmayan tutumlarını ise daha fazla kullandıkları gözlenmiştir. Depresyonu olan kişilerin stresli durumlarda, yeniden yorumlama ve gelişme yerine, alkol-madde kullanımı stratejilerine yöneldikleri gözlenmiştir (Konkan et al. 2014).

\section{Travma Sonrası Gelişim (Büyüme)}

Travma sonrası gelişim, yüksek düzeyde stres içeren yaşam krizleriyle mücadele sonucu kişilerin yaşadığı olumlu değişimleri anlatmak için kullanılan bir kavramdır. Travmatik yaşantılar kişi ya da kişilerde pek çok sıkıntı yaratsa da bu sıkıntılar kişisel gelişim için bir firsat olarak görülmekte ve travmatik yaşantı sonrasında kişilerin, travmatik yaşantı öncesine göre daha iyi bir işlevsellik düzeyine ulaştıkları görülmektedir (Tedeschi et al. 1998, 6).

Olaya bağlı olarak yaşanan stres, sosyal destek ve başa çıkma stratejileri travma sonrası 
gelişimi kolaylaştıran etkenler olarak görülmektedir (Karanc1 2005, 121). Duygusal zorlanmalarla baş edebilme yeteneğinin gelişmiş olması ve güvenilir yetişkinlere sahip olma (evde, okulda ve çevrede) intihar girişimini azaltmaktadır (Pisani et al. 2013).

Travma geçiren her kişide, travma sonrası gelişim görülecek diye bir kural yoktur. Gelişim değişik oranlarda görülür. Bu oranlar \%3-98 arasında değişmektedir. Tedeschi ve Calhoun’a göre: Travma geçirenlerin 2/3'ünde olumlu değişimler görülmektedir. Travma ile baş etme ve travma sonrası gelişimde kişilik özellikleri önemlidir (Calhoun \& Tedeschi 2006, 15).

6. Eğitim, Meslek ve Ekonomik Durum: Tamamlanmış intiharlar daha çok eğitim düzeyi düşük gruplarda olmaktadır. TÜİK verilerine göre 2012 yılında intihar edenlerin \%31,7'sini, 2013 yılında da \%38,4'ünü ilkokul mezunları oluşturmaktadır. Okumuşlarda, erkeklerin intihar oranı daha fazla iken, okula gitmemiş ve eğitimleri ilköğretim düzeyinde kalmışlarda, kadınların oranı daha fazladır (www.tuik.gov.tr/PreHaberBultenleri.do?id=15853; www.tuik.gov.tr/PreHaberBulteni.do?id=16049).

Eğitim düzeyi düştükçe, intihar girişimleri ve intiharlar artmaktadır (Aysev 1992; Deveci et al. 2005; Aktepe et al. 2006; Arslan et al. 2008; Soylu et al. 2013). Erkeklerde, düşük gelir düzeyine sahip olmak, kadınlarda ise, eğitim düzeyinin düşük olması intihar girişimleri ile ilişkili bulunmuştur (Zhang et al. 2005).

Bir mesleği olmayan öğrenci, işsiz ve ev hanımlarında intihar girişimi ve intihar oranları daha yüksektir (Özgüven \& Sayıl 2003). Bir işte çalışma ve bireyin enerjisini belli bir alana yönlendirmesi, intihar riskini azaltmakta, işsizlik ise intihar riskini artırmaktadır. Londra'da yapılan bir çalışmada, işsizlerde intihar oranı genel toplumdan üç kat daha fazla bulunmuştur (Yüksel 2001).

İşsizlikle intihar oranları arasında güçlü bir bağlantı vardır. İşsizliğin getirdiği fakirlik, sosyal yoksunluk, aile sorunları ve ümitsizlik intihar eğilimini artırmaktadır. Ruh sağlığı sorunu olan bireylerin işsizlik sorunu ile karşılaşma olasılıkları daha fazladır (Moscicki 1997; T.C. Sağlık Bakanlığı Temel Sağlık Hizmetleri Genel Müdürlüğü, İntiharın Önlenmesi Hekimler İçin Kaynak 2004, 12).

Yoksunluğun ve açlığın biyolojik etkileri kadar, psikososyal ve davranışsal etkileri de önemlidir. Yoksul ailelerin çocuklarında saldırganlık, hiperaktivite ve huzursuzluk sık görülen özelliklerdendir. Bu çocuklar, huzursuz ruh halleri ve yorgunlukları nedeniyle başka çocuklarla iletişim kurmakta zorlanırlar. Yoksul çocuklar arasında intihar girişimi ve intihar oranları daha fazladır. Yoksul evlerinde anne ve baba şiddeti daha fazla görülmektedir (Hatun et al. 2003).

Ekonomik durumu orta ve kötü olan aile çocuklarında intihar girişimi daha fazla olmaktadır (Aktepe et al. 2006; Soylu et al. 2013). Ülkemizde, intihar girişimi ile ilgili hastane çalışmalarının kamu ve üniversite hastanelerinde yapıldığı görülmektedir. Bu hastaneler, daha çok orta ve düşük gelir düzeyi olan insanların gittikleri yerlerdir. Gelir düzeyi yüksek olanların gittikleri özel tıp merkezleri ve özel hastanelerle ilgili herhangi bir çalışmaya rastlanmamıştır (Alsancak et al. 2010).

İntihar girişimleri şehirlerde, kırsal bölgelerden daha fazla görülmektedir (Aktepe et al. 2006; Eskin et al. 2006). Bazı ülkelerde de bunun tam tersi olabilmektedir (T.C. Sağlik Bakanlığı Temel Sağlık Hizmetleri Genel Müdürlüğü, Intiharın Önlenmesi Hekimler İçin Kaynak 2004, 12).

7. Seçilen Yöntemler: Ülkemizde yapılan çalışmalarda, intihar girişiminde kullanılan başlıca yöntemlerin yüksek doz ilaç ve zehirli maddeler, kesici-delici aletler, ateşli silah, yüksekten atlama, as1 ve diğerleri olarak sıralandığı görülmektedir (Aysev 1992; Ertemir \& Ertemir 2003; 
Deveci et al. 2005; Arslan et al. 2008; Gökçen \& Köylü 2011; Şevik et al. 2012). 2012 y1lına ait TÜİK verilerine göre intihar edenlerin kullandıkları yöntemler: Erkeklerde, \%51,5'i kendini asarak, \%28,8'i ateşli silahla, \%7,5'i yüksekten atlama ve \%12,2'si diğerleridir ( ilaçlar, zehirli maddeler vb.leri). Kadınlarda, \%48,6'sı kendini asarak, \%17,3'ü yüksekten atlama, \%15'i ateşli silah ve \%19,1'i diğerleridir (ilaçlar, zehirli maddeler vb.leri) (www.tuik.gov.tr/PreHaberBultenleri.do?id=15853).

Avustralya'da intihar yöntemleri ile ilgili olarak yapılan bir çalışmada (25 yaş altı): Erkeklerde, asma-boğma, ateşli silah, ilaç ve zehirler, yüksekten atlama. Kadınlarda, asma-boğma, ilaç ve zehirler, ateşli silah ve yüksekten atlama şeklinde sıralanmaktadır (Rozicka \& Choi 1999).

Belçika'da 15-24 yaş arası intihar yöntemleri ile ilgili olarak yapılan bir çalışmada: Erkeklerde, ev gazı, ateşli silah, ilaç ve zehirler, yüksekten atlama ve asma. Kadınlarda, ilaç ve zehirler, ateşli silah ve asma şeklinde sıralanmaktadır (Moens et al. 1988).

ABD'de intihar girişimleri konusunda ergenlerde yapılan bir çalışmada: Erkeklerde, asmaboğma, yüksek doz ilaç, kesici-delici aletler ve diğerleri. Kadınlarda, yüksek doz ilaç, kesici delici aletler, asma-boğma ve diğerleri (Yoder et al. 1998).

İntihar girişimleri ve intiharla ilgili yöntemler ülkelere ve bölgelere göre değişmekte olup, herkes çevresinde bulduğu ya da bulabildiğiyle eylemi gerçekleştirmektedir.

8. Önceki İntihar Girişimleri: İntihar sonucu ölenlerin yaklaşı \%44'ü daha önce intihar girişiminde bulunmuştur. Bir intihar girişiminin ardından ilk bir yıl, özellikle de 3-6 aylık dönem, tekrar intihar girişimi yönünden en riskli dönemdir (Can \& Say1l 2004).

Daha önceleri intihar girişim öyküsünün olması, daha sonra intihar tamamlama riskini erkeklerde 30, kadınlarda ise üç kat artırmaktadır (Tüzün 2005).

Tüm intiharların ortalama \%19-24'ünde daha önceden intihar girişimi öyküsü bulunmaktadır (Gökçen \& Köylü 2011). İntihar girişiminde bulunanların \%61,3'ü daha önce de intihar girişiminde bulunmuştur (Ertemir \& Ertemir 2003). Yapılan bir çalışmaya göre, kadınların \%90,3'ü bir kez, \%8,1'i iki kez, \%1,6's1 dört kez; erkeklerin \%85,7'si bir kez, \%14,3'ü iki kez intihar girişiminde bulunmuşlardır (Özgüven et al. 2003). Başka bir çalışmada da olguların \%84'ü bir kez, \%16'sı ise iki-dört kez arasında intihar girişiminde bulunmuştur (Öztop et al. 2009).

ABD'de 7978 öğrenci üzerinde yapılan bir çalışmada, öğrencilerin \%8,6'sının son bir yıl içinde intihar girişiminde bulundukları, bunlarında \%50'sinin bir kez, \%29'unun iki-üç kez, \%8'inin dört-beş kez, \%13'ünün altı ve daha fazla sayıda intihar girişiminde bulundukları gözlenmiştir. Kızların \%11'i ve erkeklerin \%6,2'si intihar girişiminde bulunmuştur (Pisani et al. 2013). Tamamlanmış intiharı olan ergenlerin \%10-40'ında daha önceden bir intihar girişimi olduğu gözlenmiştir (Miller \& Glinski 2000).

Değişik çalışmalarda, intihar girişiminde bulunanların bir kısmının bu eylemlerini ikinci kişilere bildirdikleri görülmektedir. Çalışmalara göre bu oranlar: \%46,91(Arslan et al. 2008), \%38,7 (Ertemir \& Ertemir 2003), \%80 (Can \& Say1l 2004), \%12 (Şevik et al. 2012) arasinda değişmektedir.

İntihar girişimleri genellikle evde olmaktadır. Verilen oranlar, \%87-89 arasında değişmektedir (Deveci et al. 2005; Ertemir \& Ertemir 2003; Öztop et al. 2009). İntihar girişiminde bulunanların \%8-12'si not bırakmaktadır (Deveci et al. 2005; Şevik et al. 2012). İntihar eden 1507 kişinin bırakmış oldukları notları inceleyen B. Boismont, çoğunluğun kızgınlık ve ciddi bir bezginlik durumunu anlattığını yazmıştır (Durkheim 2013, 329). 
İntihar eden ergenlerin \%35'inin kanında yüksek oranda alkol bulunduğu belirtilmiştir (Miller \& Glinski 2000). İntihar girişimi öncesi alkol kullanımı ortalama \%14 (8-19) oranındadır (Özgüven et al. 2003).

9. İnanç (Din) Etkileri: Din, olaylarla baş etme düzeyini artırarak intiharı engellemede önemli rol oynamaktadır (Altuntop 2005). Katoliklerde intihar oranı düşük, Protestanlarda yüksektir. Hristiyan toplumu kurulur kurulmaz intiharı yasaklamıştır. 452 yılında toplanan Arles Konseyi, intiharın bir suç ve şeytanın uyandırdığı aşırı öfkenin sonucu olabileceğini ilan etmiştir.

Yahudilik intiharın en az olduğu inanç topluluğudur. Yahudilerde; "kendi kendilerini isteyerek öldürenlerin cesetleri gün batmadan gömülmez” (Durkheim 2013, 188).

İslamiyet intiharı yasaklamıştır. Kur'an-1 Kerim, Nisa Suresi, 29. Ayet: “Birbirinizi öldürmeyin/Nefislerinizi öldürmeyin/Kendinizi öldürmeyin” demektedir (Ersoy 2012, 82).

Gençler arasında, Tanrı'ya inanç ile intihar arasındaki ilişkiye bakıldığında, inancı olmayanlarda intiharı normal bir davranış olarak görme eğilimi \%22, inancı olanlarda \%10 kadardır (Ulusoy et al. 2005).

10. Cinsel Tercihler: Cinsel yönelimler ile intihar düşüncesi arasında bir ilişki olduğu, gay, lezbiyen ve biseksüel ergenlerde, heteroseksüellere göre intihar düşüncelerinin \%50-70 oranında, intihar girişimlerinin ise $\% 30$ oranında daha fazla olduğu belirtilmektedir (Rutter \& Soucar 2002 ).

Başka bir çalışmada, biseksüel-homoseksüel erkeklerde intihar girişimi \%28,1, heteroseksüel erkeklerde ise \%4,2'dir. Biseksüel-homoseksüel kadınlarda intihar girişimi \%20,5, heteroseksüel kadınlarda ise $\% 14,5$ 'dir. Cinsel tercihleri farklı olanlar, normal olanlara göre 3,4 kat daha fazla intihar girişiminde bulunmaktadır (Miller \& Glinski 2000).

11. Mevsimler: İntihar girişimlerinde seçilmiş bir mevsim ya da ay yoktur. Ancak bazı çalışmalarda değişik sonuçlara rastlanmaktadır. Genel olarak Ağustos, Temmuz, Mayıs aylarında ve Yaz mevsiminde fazla olmaktadır (Şevik et al. 2012). Mevsim olarak bir farklılık yoktur. En çok Mayıs ve Ekim aylarında olmaktadır (Gökçen \& Köylü 2011). Mayıs ve Haziran aylarında en fazla görülmektedir (Aktepe et al. 2006; Öztop et al. 2009). Ülkemizde, Mayıs ve Haziran aylarında okul döneminin sonuna gelindiğinden, ergenlerde ders başarısızlıklarının sonucu ve buna bağlı olarak da anne-baba ve ergen çatışmaları tetikleyici rol oynamaktadır.

İntiharlar en çok, doğanın en güler yüzlü ve ısının da en tatlı olduğu Yaz mevsiminde olmaktadır. İnsan, yaşamın en kolay olduğu zamanda ondan ayrılmayı tercih etmektedir. İntiharlar gündüz daha çok olmaktadır. Çünkü gündüzün insan ilişkileri birbirine karışıp kesişmekte ve toplumsal yaşam daha yoğun olmaktadır (Durkheim 2013, 102, 103, 117, 120).

Bir çalışmada intihar girişiminin amacı: Ölmek ve kurtulmak \%56, sorunlardan kurtulmak $\% 16$, yardım çağrısı $\% 7$, kendine zarar verme $\% 7$, nedeni bilinmeyen $\% 11$, şüpheli $\% 3$ olarak bulunmuştur (Şevik et al. 2012).

12. Göç: İnsanın fiziksel çevresinde yaptığı bir değişiklik olan göç, çok çeşitli ekonomik, sosyal, kültürel, siyasal ve psikolojik sorunları da beraberinde getirir. Göç yaşayan kadın, erkek ve çocukların önemli ekonomik, sosyal ve politik sorunlarının yanı sıra, aile yapıları değişmekte ve çevreye uyum güçlükleri olmaktadır (Aker 2005, 58, 59).

Göç ve eşlik eden fakirlik, barınma sorunları, sosyal destek yoksunluğu ve karşılanmayan gereksinimler intihar riskini artırmaktadır (T.C. Sağlık Bakanlığı Temel Sağlık Hizmetleri Genel Müdürlüğü, İntiharın Önlenmesi Hekimler İçin Kaynak, 2004, 13). Bireyin çevre ile uyumsuzluğu, etkileşimlerini, üretkenliğini ve kendi içindeki denge durumunu bozar. Her toplum, tarihinin 
her döneminde intihar konusunda belli bir eğilime sahiptir (Durkheim 2013, 30).

Göç sonucu, ergen yeni bir çevreye taşınır, arkadaşlarından uzaklaşır, yeni bir ortam ve okula girme ile ilgili uyum sorunları, arkadaş sorunları, dışlanma ve aşağılanma gibi sorunlar yaşayabilir. Bu sorunlar ergende intihar girişimi için tetikleyici rol oynayabilir.

13. Medya: Medyanın sahip olduğu yönlendirici güç, sorumluluk bilinciyle, kontrollü ve duyarlı biçimde kullanıldığ 1 takdirde, olumsuz etkilerin aksine toplumu intihar edimi hakkında eğitmekte, intiharları önlemekte ya da yardıma gereksinim duyulduğunda, ulaşılabilecek profesyonel yardıma yönlendirmekte yardımcı olabilir (Savur et al. 2008).

G. Comstack, 30 yıl gibi bir sürede televizyonlardaki şiddetin etkisi üzerine yapılmış birçok araştırmayı gözden geçirmiş ve şiddet içeren bölümlere seyretmekle, çocuklarda antisosyal davranışlar arasında güçlü bir ilişki bulmuştur. Medya, saldırgan davranışları artırma yönünde etkili ancak tek başına belirleyici değildir (Palabıyıklığlu 1997).

19. yüzyılda J. W. Goethe tarafindan yazılan "Genç Werther'in Acıları" kitabının yayınlanmasının ardından, gençler arasında intihar oranlarında artışlar ortaya çıkmış ve zaman içinde kitap yasaklanmıştır (Atay \& Kerimoğlu 2003).

Medyanın intiharları yayınlaması ve tekrar tekrar göstermesi intiharlarda artışa yol açabilir. Bandura (1986) tarafından yapılan çalışmada: Marilyn Monroe'nin ölümünden sonraki ayda intiharlar \%12 artmıştır. Ünlü kişilerin doğal ölümlerinin yayınlanması intiharlarda atışa yol açmamaktadır. Bu da etkili etkenin üzüntü olmadığını göstermektedir. Ünlü olmayan kişilerin de intiharlarının yayınlanması sonrasında, intihar oranlarında artışlar görülmektedir. Burada, intiharların yayınlanmasının ve tekrar tekrar vurgu yapılmasının rolü üstünde durulmaktadır (akt. Savaşır 2004, 264).

Yansılamaya (taklit) bağlı olarak bireysel intiharlarda artış görülebilir. Yansılama, bask1lanmış duygu ve düşüncelerin ortaya çıkmasını tetikleyebilir (Durkheim 2013,148).

14. Fiziksel ve Ruhsal Etkenler: Hastalık, birey için biyolojik, ruhsal, sosyal, çevresel, ailesel ve cinsel olmak üzere çok boyutlu bir kavramdır. Bireyin fiziksel, duygusal, sosyal, ruhsal ve entelektüel işlevlerini azaltır ya da tüketir. Bireyin çevre ile uyumunu, etkileşimini, üretkenliğini ve kendi içindeki denge durumunu bozar. Genel nüfusun \%18'inde ruhsal bozukluklar görülmektedir (Özkan 1993, 7, 156). Kişinin içinde bulunduğu ortamda konumunu koruyabilmesi iç ve dış uyaranlara karşı uyumlu davranışlar sergileyebilmesine bağlıdır. Uyum: Düşünce, ruh, beden ve toplum dörtlüsünün karşılıklı iletişiminden etkilenmektedir (Özkan 1993, 18-19). Beden sağlığ bozuklukları, kısa boyluluk, şişmanlık, tipini beğenmeme, cinsel tercih çatışmaları, istismar ve ihmaller, cinsel kimlik arayışları, alışkanlıklar (alkol-madde kullanımı-bağımlılık). Tecavüz, evlilik dışı gebelik, cinsel yaşam konusunda suçluluk duyguları, ümitsizlik, yalnızlık, saldırganlık, öfke, sevgilisinden ayrılma ya da terk edilme, asosyal davranışlar, zayıf duygu kontrolü, mükemmeliyetçilik, aşırı duygusallık veya duyguların kontrol edilememesi, okul, iş ve arkadaşlar arasındaki olumsuzluklar, derslerin kötülüğü, sınav kaygısı ve başarısızlık gibi tehdit edici sorunlar. İstediği okula girememe (lise-üniversite), baş etme yöntemlerini yeterince kullanamama, ruhsal yaşam ve ruh hastalıkları, fiziksel zorbalık, siber zorbalık, şiddet davranışı, aileden birisinin ya da arkadaşının intihar ya da intihar girişimi, intiharların medyada verilişi ve depresif duygu durum bozukluklarının intihar düşüncesi, intihar girişimi ve intihar davranış1 üzerinde etkili olduğu gözlenmiştir (Aysev 1992; Dilsiz \& Dilsiz 1993; Allen 1995, 142-143; Eskin 2000; Yüksel 2001; Ceyhun \& Ceyhun 2003; Aktepe et al. 2006; Liu 2006; Öztop et al. 2009; Gökçen \& Köylü 2011; Byers 2013; Litwiller \& Brausch 2013; Pisani et al. 2013; Crepeau-Hobson \& Leech 2014). 
İntihar girişiminde bulunan ergenlerin \%77,8'inin psikiyatrik rahatsızlığının bulunduğu ve literatür taramalarında da bu oranın \% 80-90 arasında değiş̧tiği görülmektedir. Yapılan bir çalışmada: İntihar girişimi öncesi olguların \%58,3'ünün psikiyatrik tedavi için başvurularının olduğu görülmüştür (Akın \& Berkem 2012). Bir başka çalışmada da, öz geçmişlerinde psikiyatrik rahatsızlığı bulunanların \%36'sının intihar girişiminde bulunduğu görülmektedir (Öztop et al. 2009). İntihar düşünce ve davranışı ile psikiyatrik bozukluklar arasında yakın bir ilişki bulunmaktadır. Psikiyatrik hastalığı olanlarda intihar görülme sıklığı diğer gruplardan 5 ile 40 kat daha fazladır (Yüksel 2001).

Kendini öldürmeyi düşünen ve öldürmek için girişimde bulunan gençlerin, böyle düşünmeyenlere göre daha fazla ruhsal sorunlara sahip oldukları görülmektedir (Eskin 2000).

Çocukluk çağındaki cinsel istismar, fiziksel istismar, duygusal istismar ve ihmallerin ergenin intihar düşüncesi ve intihar girişimi ile yakından ilişkili olduğu görülmüşsür (Miller et al. 2013). Yapılan bir çalışmada: Kadınların 1/3'ünün çocukluk ve ergenlik çağında cinsel istismara uğradığı, bunların da \%60'ının erken dönemde intiharı düşündükleri, \%20'sinin bir ya da daha fazla sayıda intihar girişiminde bulundukları, geç dönemde ise \%43'ünün intiharı düşündüğü ve \%14'ünün intihar girişiminde bulunduğu gözlenmiştir (Teegen 1999, 101-102).

Ergenlik dönemindeki ruhsal olaylar aynı zamanda bireyin yetişkinlikteki ruh sağlı̆̆ını etkilemektedir. Offer ve arkadaşları bir grubun, 14-19 ve 48 yaşlarındayken inceledikleri ruhsal durumlarının boylamsal değerlendirilmesinde: 14 yaşındaki psikolojik durumun etkisini, 48 yaşındayken de gösterdiğini saptamışlardır. 14 yaşında iken yaşamdan zevk almayan ve üzüntülü olan ergen, 19 yaşında iken kendini sevmemekte ve 48 yaşında da ağlama, kendini suçlama, değersizlik hissi, duygusal yetersizlik, düşük enerji ve intihar düşüncesi gibi psikolojik sorunları yaşadıkları belirlenmiştir.

14 yaşında iken, düşük duygusal düzey, düşük mental düzey ve zayıf beden algısı olan ergen; 19 yaşına geldiğinde özgüven eksikliği oluşmakta ve bu süreç 48 yaşına gelindiğinde depresyon olarak karşımıza çıkmaktadır.

14 yaşında iken, zayıf sosyal ilişki, düşük duygusal düzey, düşük mental düzey ve zayıf beden algısı taşıyan ergen; 19 yaşına geldiğinde duygusal donukluk, kendilik ifadesinde zayıflık ve öz güven eksikliği yaşamakta ve bu süreç 48 yaşına gelindiğinde fobik anksiyete olarak karşımıza çıkmaktadır (Offer et al. 1998).

Ergenlerin intihar düşüncesi, intihar girişimi ve intiharla ilişkili olan başlıca psikiyatrik bozuklukları: Affektif bozukluklar, depresyon, bipolar bozukluklar, uyum bozuklukları, alkol ve madde kötüye kullanımı, şizofreni, antisosyal kişilik bozukluğu, anksiyete bozuklukları, dikkat eksikliği ve hiperaktivite bozukluğu, davranım bozukluğu, konversiyon bozukluğu, obsesif kompulsif bozukluk, yeme bozukluğu, panik atak ve travma sonrası stres bozukluğudur (Miller \& Glinski 2000; Yüksel 2001; Winter \& Koger 2004, 46-47; Tüzün 2005; Lachar 2011, 71; Akın \& Berkem 2012; Liu 2006; Pisani et al. 2013).

İntihar öncesi ergenlerde dikkat çekici bazı davranışlar bulunabilir. Bunlar:

- Saldırgan ve isyankar davranışlarda artma (Huy ve davranışlarda değişme).

- Belirgin kişilik değişiklikleri ve değer yargılarına karşı ilgisizlik.

- Sürekli sıkıntı, dikkat toplamada güçlük, okul başarısında düşme ve derslere karşı ilginin azalması.

- Kendisine ve çevresine yabancılaşma ve bazı aktivitelerden vazgeçme.

- Duygulanım bozukluğu, alkol ve madde kullanımının varlığı. 
- Dağınıklık, beslenme bozukluğu ve uyku düzeninde bozulmalar (Ziyalar 1999, 140; Atay \& Kerimoğlu 2003).

\section{Önleyici Tedbirler ve Sonuç}

Risk altında bulunan her çocuk ve ergen intiharı düşünür ya da intihar eder diye bir kural yoktur. Ergeni de koruyan bazı etkenler vardır. Bunların başında, kişilik özellikleri, bilişsel beceriler ve başa etme becerilerinin gelişmesi gelir. İyi huylu, bilişsel becerileri daha iyi olan, güçlü sözel ve iletişim becerilerine sahip olan, olayların iyi yönlerini de görebilen, gereğinde esnek davranabilen, olumlu öz değer duygusu gelişmiş, sosyal anlamda etkileyici kişilik yapısı, mutlu ve huzurlu bir aile ortam1, önemli koruyucu etkenlerdendir (Moscicki 1997; Ekşi 2011, 367).

Herkes sorunlar karşısında değişik derecelerde bunalabilir, fakat burada önemli olan, sorunlarla baş etme yöntemlerinin bilinmesi ve olumlu yaklaşımla sorunların çözülmesidir.

İntihar, belli oranlarda önlenebilir ölüm nedenleri arasındadır. Tıpkı trafik kazalarından ölenlerin, önleyici tedbirler sonucu azalması gibi. Ülkemizde 2004 yılında 537.352 trafik kazas1 olmuş ve 4427 kişi kaza sonucu ölmüşken, 2013 yılında 1.207.354 trafik kazası olmuş ve 3685 kişi ölmüştür (http://www.tuik.gov.tr/PreHaberBultenleri.do?id=18510).

Derslerinin yanı sıra öğrencilerin ruhsal ve sosyal yönden sağlıklı gelişmeleri de önemlidir. Ergenlerin ruhsal gerilimini azaltıcı, sosyal yönlerini geliştirici, ders dışı sosyal ve kültürel etkinliklerin artırılması, özendirilmesi, sportif etkinliklere yönlendirilmesi, yaşamın sadece derslerden ve ders notlarından ibaret olmadığının bilinmesi, önemli koruyucu etkenler arasındadir (Moscicki 1997; Ceyhun \& Ceyhun 2003; Taliaferro 2008; Ramey 2010).

İntihar düşüncesi, intihar girişimi ve intihar bireysel, ailesel, toplumsal, sosyal, siyasal, ekonomik, kültürel, sağlık ve coğrafi konum gibi pek çok etkene bağlı olan, iç içe girmiş, karmaşık olaylar zincirinin bir sonucu olarak ortaya çıkmaktadır. Bu kadar karmaşık bir olaydan sınırlı da olsa korunmak ciddi emek, yatırım ve özveri istemektedir.

Bir olayın gerçek nedenini belirlemek her zaman kolay olmamaktadır. İntihar edenin, bu eylemden önce yaşadığı olaylar arasında; insanı genellikle umutsuzluğa düşüreceği kabul edilen kimi etkenleri bulduğumuzu sandığımız anda araştırmayı ilerletmeyi gereksiz görürüz. Örneğin: İntihar girişiminde bulunan ya da intihar eden kişi, aile içi üzücü olay yaşamış ya da ekonomik sorunlar yaşamış/yaşıyorsa, intihar nedeninin bunlar olduğu sonucuna varırız. Oysa bunlar her zaman gerçek intihar nedenleri olmayıp sadece tetikleyici olabilirler (Durkheim 2013, 158). Genellikle aile içi sorun yaşayan ya da ekonomik sorunları olan herkes intiharı düşünmemekte ve intihar etmemektedir.

Önleyici tedbirlerin etkin olması için olayın temel kaynağı ve tetikleyici etkenlerinin bulunup çözümlenmesi gerekir. Aile içi ciddi sorunlar yaşayan (istismar edilen) bir ergenin sorunu, sadece okuldaki rehberlik öğretmeni ile çözülemez. Olayın ciddiyetine göre sağlık kurumları, sosyal kurumlar, sivil toplum örgütleri, çocuk izleme merkezleri (ÇiM) ve adli kurumlar devreye girebilir. Sorunu olan çocuk ya da ergen, sağlık, sosyal ve ekonomik desteklerin yanı sıra, devlet koruması altına da alınabilir.

Görsel ve yazılı medya bu konuda duyarlı olmalı, yıkıcı değil yapıcı ve eğitici programlar yapmalıdır.

İlaç, ateşli silah ve zehirli maddelerin temin ve ulaşımının zorlaştırılması, çocuk ve ergenlerin kolayca ulaşamayacağı yerlerde saklanması önem arz eder.

Okullarda, çocuk ve ergenlere günlük yaşamlarında sorun çözme becerilerinin geliştirilmesi ile ilgili bilgilerin verilmesi, düşünce yetilerinin geliştirilmesi ve neden-sonuç sorgulaması yapa- 
bilmeye yönelik eğitim verilmesi ruh sağlıkları ve gelecekleri yönünden yararlı olacaktır. Özenle yetiştirilmiş çocuklar aydınlık bir gelecektir. İhmal edilmiş, örselenmiş ve yarım yamalak yetiştirilmiş çocuklar, alaca karanlıkta tünele giren, geleceği karanlık ve karmaşık sorunlarla dolu olan, kişi ya da kişiler olacaklardır. Bugünün sorunları dünde, yarının sorunları da, bugün de saklıdır.

\section{KAYNAKÇA}

Agerbo E., Nordentoft M. \& Mortensen P. B. (2002). "Familial, psychiatric and socioeconomic risk faktors for suicide in young people: nested case-control study”. BMJ 325 (2002) 1-5.

Akalın Ş. H. (2011).Türkçe Sözlük. Ankara 2011.

Aker A. T. (2005). "Zorunlu İç Göçün Ruhsal Sonuçları ve Dönüş Sonrası Yansımaları”. IV. Uluslararası Ruhsal Travma Toplantılarl Özet Kitabı 58-59 (2005) 1-4 Aralık. İstanbul.

Akın E. \& Berkem M. (2012). "İntihar Girişiminde Bulunan Ergenlerde Psikiyatrik Tanıların, Demografik ve Klinik Özelliklerin Değerlendirilmesi”. Firat Tip Dergisi 17/4 (2012) 228-232.

Aktepe E., Kandil S., Göker Z., Sarp K., Topbaş M. \& Özkorumak E. (2006). "İntihar Girişiminde Bulunan Çocuk ve Ergenlerde Sosyodemografik ve Psikiyatrik Özelliklerin Değerlendirilmesi”. TSK Koruyucu Hekimlik Bülteni 5/6 (2006) 444-454.

Akvardar Y., Çalak E., Etaner U., Hürol C., Sunat H., Tükel R., Üçok A. \& Yücel B. (2006). Psikanalitik Kurama Giriş. İstanbul 2006.

Algın F. (2009). Şizofreni Hastalarında Başa Çıkma Tutumlarının Umutsuzluk, Intihar Davranışı ve İç Görü İle İlişkisi. Uzmanlık Tezi. T.C. Sağlık Bakanlığı Bakırköy Ord. Prof. Dr. Mazhar Osman Ruh Sağlığı ve Sinir Hastalıkları Eğitim ve Araştırma Hastanesi, İstanbul 2009.

Allen J. G. (1995). Coping with Trauma. Washington, DC.

Alsancak B., Ziyalar N. \& Kayaalp L. (2010). "İntihar Girişisiminde Bulunmuş Ergenlerde Depresyon ve Anksiyete, İstanbul Pilot Çalışması”. Adli Tip Dergisi 24/1 (2010) 14-21.

Altuntop H. (2005). Dindarlık-İntihar İlişkisi. Yüksek Lisans Tezi. Süleyman Demirel Üniversitesi. Isparta 2005.

Arslan M., Duru M. \& Kuvandik G. (2008). “Hatay’da İntihar Girişiminde Bulunan Olguların Analizi”. Adli Tip Dergisi 22/3 (2008) 9-14.

Atasoy E. (2013). "The geography of suicide: Russia example/ intiharlar coğrafyası: Rusya örneği”. 3rd International Geography Symposium. Eds. R. Efe, İ. Atalay \& İ. Cürebal. Kaynak: web.deu.edu.tr/geomed/proceedings/download/033_GeoMed_2013_proceeding_311-333 pdf.

Atay İ. M. \& Kerimoğlu E. (2003). “Ergenlerde İntihar Davranışı”. Çocuk ve Gençlik Ruh Sağlığı Dergisi 10/3 (2003) 128-136.

Aysev A. (1992). “İntihar Girişimi Olan Çocuklarda Yaşam Olayları”. Kriz Dergisi 1/1 (1992) 17-21.

Batıgün D. A. (2005). "İntihar Olasılı̆̆ı: Yaşamı Sürdürme Nedenleri, Umutsuzluk ve Yalnızlık Açısından Bir İnceleme”. Türk Psikiyatri Dergisi 16/1 (2005) 29-39.

Batıgün D. A. (2008). "İntihar Olasılığı ve Cinsiyet: İletişim Becerileri, Yaşamı Sürdürme Nedenleri, Yalnızlık ve Umutsuzluk Açısından Bir İnceleme”. Türk Psikoloji Dergisi 23/62 (2008) 65-75.

Bayraktar S. (2012). Psikolojik Travma. İstanbul 2012.

Bildik T. (2013). “Ölüm, Kayı, Yas ve Patolojik Yas”. Ege Tip Dergisi 52/4 (2013) 223-229.

Byers S. D. (2013). Book review. "Devastating Losses - How Parents Cope with the Death of a Child to Suicide or Drugs”. Clin Soc Work J 41 (2013) 413-415. DOI.1007/s10615-012-0431-0

Calhoun L. G. \& Tedeschi R. G. (2006). “The Foundations of Posttraumatic Growth”. Eds. L. G. Calhoun \& R. G. Tedeschi. Handbook of Posttraumatic Growth Research and Practice (2006) 3-23. London.

Can G. (2011). “Anne-Yenidoğan Bağının Önemi”. Ed. A. Ekşi. Ben Hasta Değilim (2011) 1-5. İstanbul.

Can S. S. \& Sayıl I. (2004). "Yineleyici İntihar Girişimleri”. Kriz Dergisi 12/3 (2004) 53-62. 
Ceyhun A. G. \& Ceyhun B. (2003). "Lise ve Üniversite Öğrencilerinde İntihar Olasılığının Değerlendirilmesi”. Klinik Psikiyatri 6 (2003) 217-224.

Crepeau-Hobson M. F. \& Leech N. L. (2014). "The Impact of Exposure Peer Suicidal Self-Directed Violence on Youth Suicidal Behavior: A Critical Review of The Literature”. Suicide and LifeThreatening Behavior 44 /1 (2014) 58-77.

Cüceloğlu D. (2000). İnsan ve Davranışı Psikolojinin Temel Kavramları. İstanbul 2000.

Çuhadaroğlu Ç. F. (2001). "Suicide Attempts and Self-Image Among Turkish Adolescents". Journal of Youth and Adolescence 30/5 (2001) 641-651.

Çitak A. (2011). “İntihar”. Ed. A. Ekşi. Ben Hasta Değilim (2001) 548-552. İstanbul.

Deveci A., Taşkın O., Dündar P. E., Demet M., Kaya E., Özmen E. \& Dinç G. (2005). "Manisa İli Kent Merkezinde İntihar Düşüncesi ve Girişim Yaygınlığı”. Türk Psikiyatri Dergisi 16/3 (2005) 170-178.

Dilsiz A. \& Dilsiz F. (1993). "İntihar Girişimlerinde Belirtilen Nedenler”. Kriz Dergisi 1/3 (1993) 124-128.

Durkheim E. (2013). İntihar. Çev. Ö. Ozankaya. İstanbul 2013.

Ekşi A. (2011). "Çocuğun Ruhsal Gelişiminde Annenin Önemi, Anneden Ayrıllğın Tepkileri”. Ed. A. Ekşi. Ben Hasta Değilim (2011) 38-46. İstanbul.

Ekşi A. (2011). “Gencin Ruhsal Gelişimi”. Ed. A. Ekşi. Ben Hasta Değilim (2011) 116-136. İstanbul.

Erden G. (2002). “Ölüm Sürecinde Olan Çocuk; Ölümü Kabul ve Tedavi Sürecinde Etkili Yardım”. Kriz Dergisi 10/1 (2002) 19-27.

Ersoy M. A. (2012). Kur’an Meali. Yay. Haz. R. Şentürk \& A. C. Köksal. İstanbul 2012.

Erşan E. E. \& Kılıç Ç. (2013). "Sivas Numune Hastanesi Acil Servisine Başvuran İntihar Girişimlerinin Değerlendirilmesi”. Klinik Psikiyatri 16 (2013) 98-109.

Ertemir, D. \& Ertemir, M. (2003). “Gençlerin İntihar Girişimlerinin Özellikleri”. Düşünen Adam 16/4 (2003) 231-234.

Eskin M. (2000). “Ergen Ruh Sağlığı Sorunları ve İntihar Davranışıyla İlişkileri”. Klinik Psikiyatri 3 (2000) 228-234.

Eskin M. (2001). "Ergenlikte Yalnızlık, Baş Etme Yöntemleri ve Yalnızlığın İntihar Davranışı ile İlişkisi”. Klinik Psikiyatri 4 (2001) 5-11.

Eskin M., Akoğlu A. \& Uygur B. (2006). "Ayaktan Tedavi Edilen Psikiyatri Hastalarında Travmatik Yaşam Olayları ve Sorun Çözme Becerileri: İntihar Davranışıyla İlişkisi”. Türk Psikiyatri Dergisi $17 / 4$ (2006) 266-275.

Geçtan E. (2012 ). Insan Olmak. İstanbul 2012.

Gökçen C. \& Köylü R. (2011). “Acil Servisten İntihar Girişimi Nedeniyle Psikososyal Destek Birimine Yönlendirilen 18 Yaş Altı Olguların Değerlendirilmesi”. Akademik Acil Tip Dergisi (2011) 18-21.

Gündoğmuş Ü. N., Özbek V. Ö., Özkara E., Biçer Ü. \& Yıldız M. (2004). “İntihar Girişimlerinde Sağlık Personelinin Adli İhbar Yükümlülüğü”. Adli Tip Dergisi 18/2 (2004) 38-44.

Hatun Ş., Etiler N. \& Gönüllü E. (2003). "Yoksulluk ve Çocuklar Üzerindeki Etkileri”. Çocuk Să̆glı̆ ve Hastaliklarl Dergisi 46 (2003) 451-460.

Hawton K. (2000). "Sex and Suicide. Gender Differences in Suicidal Behavior". British Journal of Psychiatry 177 (2000) 484-485.

İnal Ö. (2011). Çağdaş Dünyada İntihar Olgusu ve Yazarlık Sürecinde Kullanımı ve Bir Örnek Oyun "Buluşma". Lisans tezi. Dokuz Eylül Üniversitesi, Güzel Sanatlar Fakültesi, Sahne Sanatları Bölümü. İzmir 2011.

Kaplan H. İ. \& Sadock B. J. (2004). Klinik Psikiyatri. Çev. Ed. E. Abay. İstanbul 2004.

Karancı N. (2005). "Travmanın Farklı Bir Boyutu: Travma Sonrası Büyüme”. IV. Uluslararası Ruhsal Travma Toplantılarl Özet Kitabı 121 (2005) 1-4 Aralık, İstanbul.

Kılıç A. (2012). “Çocuk Gelin Sorunu”. Ĕgitiş̧im Dergisi 33 (2012).

Kıvılcım M. \& Doğan D. G. (2014). “Çocuk ve Ölüm”. Turgut Özal Tip Merkezi Dergisi 21/1 (2014) 80-85.

Konkan R., Erkuş G. H., Güçlü O., Şenormancı Ö., Aydın E., Ülgen M. C.\& Sungur M. Z. (2014). "İntihar Girişiminde Bulunan Kişilerde Başa Çıkma Tutumları". Araştırma makalesi. Nöropsikiyatri 
Arşivi 51 (2014) 46-51.

Kumbasar H. (1998). “İlişki Sorunları”. Eds. C. Güleç \& E. Köroğlu. Psikiyatri Temel Kitabı (1998) 548552. Ankara.

Lachar J. (2011). How to Talk to A Borderline. New York, London 2011.

Lazarus R. S. \& Folkman S. (1984). Stress, Appraisal, and Coping. New York 1984.

Leskela U. S., Melartin T. K., Lestela-Mielonen P. S., Rytsala H. J., Sokero T. P., Heikkinen M. E.\& Isometsa E. K. (2004). "Life Events, Social Support, and Onset of Major Depressive Episode in Finnish Patients”. The Journal of Nervous and Mental Disease 5 (2004) 373-381.

Litwiller B. J. \& Brausch A. M. (2013). "Cyber Bullying and Physical Bullying in Adolescent Suicide: The Role of Violent Behavior and Substance Use”. Journal of Youth and Adolescence 42 (2013) 675684.

Liu X. R. (2006). “Vulnerability to Friends’ Suicide Influence: The Moderating Effects of Gender and Adolescent Depression”. Journal of Youth and Adolescence 35/3 (2006) 479-489.

Lorcu F. \& Bolat B. A. (2009). "Yaşlara Göre Ölüm Oranları ile Sosyo-Ekonomik Göstergeler Arasındaki İlişkinin İncelenmesi”. İstanbul Üniversitesi Işsletme Fakültesi Dergisi 38/2 (2009) 124-133.

Miller A. B., Esposito-Smythers C., Weismore J. T. \& Renshow K. D. (2013). “The Relation Between Child Maltreatment and Adolescent Suicidal Behavior: A Systematic Review and Critical Examination of the Literature”. Clin Child Fam Psychol Rev 16 (2013) 146-172.

Miller A. L. \& Glinski J. (2000). "Youth suicidal behavior: Assessment and intervention”. Journal of Clinical Psychology 56/9 (2000) 1131-1152.

Moens G. F. G., Haenen W. \& Voorde H. V. D. (1988). "Epidemiological Aspects of Suicide Among The Young in Selected European Countries”. Journal of Epidemiology and Community Health 42 (1998) 279-285.

Moscicki E. K. (1997). Identification of Suicide Risk Factors Using Epidemiologic Studies. Psychiatric Clinics of North America 20 (1997) 499-517.

Offer D., Kaiz M., Howard K. I. \& Bennett E. S. (1998). “Emotional Variables in Adolescence, And Their Stability And Contribution to the Mental Health of Adult Men: Implications For Early Intervention Strategier". Journal of Youth and Adolescence 27/6 (1998) 675-690.

Özalp E. (2009). “İntihar Davranışının Genetiği”. Türk Psikiyatri Dergisi 20/1 (2009) 85-93.

Özgüven H. D., Soykan Ç. \& Haran S. (2003). “İntihar Girişiminde Sorun Alanları ve Tetikleyiciler”. Kriz Dergisi 11/1 (2003) 13-24.

Özgüven H. D. \& Sayıl I. (2003). "Suicide attempts in Turkey: results of the WHO/EURO multicentre study of suicidal behavior”. Can J Psychiatry 48/5 (2003) 324-329.

Özkan S. (1993). Psikiyatrik Tıp: Konsültasyon-liyezon Psikiyatrisi. İstanbul 1993.

Özsoy S. D. \& Eşel E. (2003). “İntihar (Öz kıyım)”. Anadolu Psikiyatri Dergisi 4 (2003) 175-185.

Öztop D. B., Özdemir Ç., Ünalan D., Akgül H. \& Şahin N. (2009). “İntihar Girişiminde Bulunan 6-16 Yaş Grubuna Ait 2002-2006 Yılları Başvuru Kayıtlarının Değerlendirilmesi”. Fırat Săglık Hizmetleri Dergisi 4/11 (2009) 159-173.

Palabıyıklığlu R. (1997). "Medya ve Şiddet”. Kriz Dergisi 5/2 (1997) 123-126. DOI: 101501/Kriz_ 0000000014.

Park H. S., Schepp K. G., Jang E. H., \& Koo H. Y. (2006). "Predictors of Suicidan Ideation Among High School Students by Gender in South Korea”. Journal of School Health 76/5 (2006) 181-188.

Pisani A. R., Wyman P. A., Petrova M., Schmeelk-Cone K., Golston D. B., Xia Y. \& Gould M. S. (2013). "Emotion Regulation Difficulties, Youth-Adult Relationships, and Suicide Attempts Among High School Students in Underserved Communities”. Journal of Youth and Adolescence 42 (2013) 807-820.

Ramey H. L., Busseri M. A., Khanna N., Hamilton Y. N., Rescau Ado Ottowa Y.N. \& Rose-Krasnor L. (2010). "Youth Engagement and Suicide Risk: Testing a Mediated Model in a Canadian Community Sample”. Journal of Youth and Adolescence 39 (2010) 243-258.

Roy A., Rylander G. \& Sarchiapone M. (1997). “Genetic Studies of Suicidal Behavior”. Psychiatric Clin. North America 20/3 (1997) 595-611. 
Ruzicka L. \& Choi C. Y. (1999). "Youth suicide in Australia”. Journal of the Australian Population Association 16 Nos.1/2 (1999) 29-48.

Salk L. (1982). Çocuğun Duygusal Sorunları, Bebeklikten-Yetişkinliğe. Çev. E. Onur. İstanbul 1982.

Sarafino E. P. (2006). Health Psychology Biopsychosocial Interactions (5.bask1). USA 2006.

Sarandöl A. (2003). “İntihar”. Birinci Basamak İçin Psikiyatri 2 (2003) 32-45.

Savaşır I. (2004). "Duygudurum Bozuklukları". Eds. Davidson, G. C. \& Neale, J. M. Çev. Ed. İ. Dağ. Anormal Psikoloji (2004) 234-271. Ankara.

Sayar M. K. \& Acar Ö. M. (2000). “Aşırı Dozda İlaç Alımıyla İntihar Girişiminde Bulunan Ergenlerde Psikolojik Etkenler”. Klinik Psikofarmakoloji Bülteni 10 (2000) 133-138.

Sayar K. \& Bağlan F. (2010). Koruyucu Psikoloji Çocuk Eğitiminde Duygusal Rehber. İstanbul 2010.

Sayıl M. (1997). “İnsanın Gelişimi: Yaşam Boyu Gelişimi”. Eds. C. Güleç \& E. Köroğlu. Psikiyatri Temel Kitabl (1997) 27-147. Ankara.

Siyez D. M. (2006). “Ergenlik Döneminde İntihar Girişimleri. Bir Bözden Geçirme”. Kastamonu Eğitim Dergisi 14/2 (2006) 413-420.

Rutter P. A. \& Soucar E. (2002). "Youth Suicide Risk and Sexual Orientation”. Adolescence 37/146 (2002) 289-299.

Soylu N., Taneli Y. \& Taneli S. (2013). "Depresyonu Olan Ergenlerde İntihar Davranışını Etkileyen Sosyal, Emosyonel ve Kognitif Faktörlerin Araştırılması”. Nöropsikiyatri Arşivi 50 (2013) 352-359.

Statham D. J., Heath A. C. \& Madden P.A. (1998). "Suicidal Behavior: An Epidemiological and Genetic Study”. Psychol. Med. 28/4 (1998) 839-855.

Şener Ş. \& İşeri E. (2011). Aile-Çocuk Etkileşimi. Ed. A. Ekşi. Ben Hasta Değilim (2011) 23-32. İstanbul.

Şevik A. E., Özcan H. \& Uysal E. (2012). “İntihar Girişimlerinin İncelenmesi: Risk Faktörleri ve Takip”. Klinik Psikiyatri 15 (2012) 218-225.

Taliaferro L. A., Rienzo B. A., Miller M. D., Pigg R. M. \& Dodd V. J. (2008). "Highschool Youth and Suicide Risk: Exploring Protection Afforded Through Physical Activity and Sport Participation”. Journal of School Health 78/10 (2008) 545-553.

Tedeschi R. G., Park C. L. \& Calhoun L. G. (1998). "Posttraumatic growth: conceptual issues”. E. R. G. Tedeschi C. L. Park \& L. G. Calhoun. Posttraumatic growth: Positive changes in the aftermath of crisis (1998) 1-22. London.

Teegen F. (1999). “Childhood Sexual Abuse and Long-Term Sequel”. Eds. A. Maercker, M. Schützwohl \& Z. Solomon. Post-traumatic stres disorder. A lifespan developmental perspective, (1999) 97-112. Seattle, Toronto, Bern, Göttingen.

Tükel R. (2006). "Yalnızlık Üzerine Notlar”. Yayın Yönetmeni: T. Parman. Psikanaliz yazıları. Yalnızlık, Sonbahar 2001. (2006) 39-43. İstanbul.

Tüzün D. Ü. (2005). “Gençlik Döneminde Depresyon ve İntihar”. İ. Ü. Cerrahpaşa Tip Fakültesi Sürekli Tlp Eğitimi etkinlikleri. Adolesan Sağllğ Sempozyumu Dizisi 43 (2005) 53-58.

Ulusoy D., Demir N. Ö. \& Baran A. G. (2005). "Ergenlik Döneminde İntihar Algısı: Lise Son Sınıf Gençliği Örneği”. Hacettepe Üniversitesi Edebiyat Fakültesi Dergisi 22/1 (2005) 259-270.

Ünlü G., Aksoy Z. \& Ersan E. E. (2014). "İntihar Girişiminde Bulunan Çocuk ve Ergenlerin Değerlendirilmesi”. Pamukkale Tip Dergisi 7/3 (2014) 176-183.

Winter D. D. N. \& Koger S. M. (2004). The Psychology of Environmental Problems. London 2004.

Verona E. \& Javdani S. (2011). "Dimensions of Adolescent Psychopathology And Relationships to Suicide Risk Indicators”. Journal of Youth and Adolescence 40 (2011) 958-971.

Yalaki Z., Taşar M. A.,Yalçın N. \& Dallar Y. (2011). "Çocukluk ve Gençlik Dönemindeki Öz Kıyım Girişimlerinin Değerlendirilmesi”. Ege Tip Dergisi 50/2 (2011) 125-128.

Yavuzer, H. (2001). Çocuk ve Suç. İstanbul 2001.

Yılmaz, S. (2013). "Çocuklarda Ölüm Kaygısının Çeşitli Değişkenler Açısından İncelenmesi”. Bilimname, Düşünce Platformu XXV/2 (2013) 169-189.

Yoder K. A., Hoyt D. R. \& Whitbec L. B. (1998). "Suicidal Behavior Among Homeless and Runaway 
Adolescents”. Journal of Youth and Adolescence 27/6 (1998) 753-771.

Yüksel N. (2001). “İntiharın Nörobiyolojisi”. Klinik Psikiyatri Ek 2 (2001) 5-15.

Zhang J., Mckown E., Hussey J. R. \& Woods J. R. (2005). “Gender Differences in Risk Faktors For Attempted Suicide Among Young Adults: Findings From the Third National Health and Nutrition Examination Survey”. Annals of Epidemiology 15 (2005) 167-174.

Ziyalar, A. (1999). Sosyal Psikiyatri. İstanbul 1999.

T.C. Sağlık Bakanlığı Temel Sağlık Hizmetleri Genel Müdürlüğü (2004). Intiharın Önlenmesi Hekimler İçin Kaynak. Çev. T. Kurtuluş \& A. T. Demirtaş. Dünya Sağlık Örgütü tarafindan 2000 yılında "İntiharı Önlemek" Genel Hekimler İçin Bir Kaynak (WHO/MNH/MBD/00/1) Ankara.

\section{İnternet Kaynakları}

Haberciniz.biz/uc-yilda-9-bin-kisi-intihar-etti-3155788h.html. (Erişim Tarihi:20.11.2014). Kaynak: CHA.

Savur, E., Cengiz, S. A. \& Karakuş, N. (2008). "Yılında Ulusal Basında Yer Alan İntihar ya da İntihar Girişimi Konulu Haberlerde Etik Sorunlar”. Kaynak: http://intiharionleme.org/calisma.pdf. 28.12.2012. Erişim Tarihi: 20.11.2014.

Unicef Türkiye'de çocukların durumu raporu 2011. http://www. izmiriplanlıyorum.019/static/upload/file /turkıye'de_cocuklarin_durumu_raporu_(2011).pdf. Erişim Tarihi: 14.10.2014.

www.tuik.gov.tr/PreHaberBultenleri.do?id=15853. Erişim Tarihi: 30.10.2014.

www.tuik.gov.tr/PreHaberBultenleri.do?id=16049. Erişim Tarihi: 30.10.2014. http://www.tuik.gov.tr/ PreHaberBultenleri.do?id=18510. Erişim Tarihi: 10.11.2014.

www.egitimajansi.com/haber/okullar-aciliyor-yeni-egitim-ogretim-yilinda-neler-olacak-haberi-

32448h.html. Erişim Tarihi:17.11.2014.

www.muhabir.net/saglik/artan-intiharlar-stratejik-plana-dahil-edildi-h1343.html. Erişim Tarihi: 17.11.2014. 